Héthelyi Máté

\title{
Halál és halhatatlanság a Phaidónban
}

\section{Bevezető}

Az alábbiakban Platón Phaidónjának egy részletét (105e6-107b10) tárgyalom, melyben Szókratész abból, hogy bebizonyította a lélek halhatatlan (athanatosz) voltát, arra következtet, hogy a lélek elpusztíthatatlan (anólethrosz). Az érvet több szerző is hibásnak tekinti a Platón-szakirodalomban - például Taylor, Bostock -, ugyanis abból, hogy valami halhatatlan nem következik, hogy egyben elpusztíthatatlan is. ${ }^{1}$ Kritikusai szerint Szókratésznek további bizonyítékokat kellett volna felhoznia amellett, hogy következtetése helytálló. A következőkben amellett érvelek, hogy a Phaidón korábbi részeiben a halállal és halhatatlansággal kapcsolatban elfogadott premisszák lehetővé teszik, hogy a lélek halhatatlanságából rögtön elpusztíthatatlanságára következtethessünk, aminek fontos előfeltevése, hogy a halált és halhatatlanságot Szókratész az elemzendő szakaszban sokkal szélesebb, metafizikai kontextusban érti, mint ahogy az első pillantásra látszik. Nem gondolom viszont, hogy a dialógusban végig azonos meghatározások vonatkoznának a halálra és halhatatlanságra. Ezért elkülönítem majd azokat a premisszákat, meghatározásokat, melyek a szöveg elejétől fogva jelen vannak azoktól, melyek csak később jelennek meg, a korábbiakat felváltva, kiegészítve. Érvelni fogok amellett, hogy miért valószínűbb, hogy Szókratész a vonatkozó részletben a később megjelenő meghatározásokra támaszkodik, illetve röviden elemzem azt az érvet (az úgynevezett affinitás érvet), ahol a premisszák második csoportja megjelenik. Röviden jellemzem a Phaidónban megjelenő lélekelméletet is, elsősorban azt, ami az affinitás érvben és az utolsó érvben szerepel. A lélekelmélet és a halál-halhatatlanság elmélet kapcsolatba hozatalával mutatom majd meg, hogy miért következik - a szókratészi meghatározások szerint - a lélek természetéből nemcsak az, hogy halhatatlan, hanem az is, hogy általában elpusztíthatatlan.

1 Köszönettel tartozom a VII. Mathéma Konferencia szervezőinek, hogy lehetőséget adtak írásom egy előzetes változatának előadására. Köszönettel tartozom továbbá Bárány Istvánnak, Faragó-Szabó Istvánnak és Kendeffy Gábornak, akik hasznos megjegyzéseikkel segítettek, hogy a szöveg elnyerje végső formáját. Szeretnék köszönetet mondani a dolgozat lektorának, Máté Andrásnak, alapos és segítőkész lektori munkájáért. 


\section{Szókratész utolsó érve a lélek halhatatlansága mellett}

Annak érdekében, hogy könnyebben átlássuk az érv szerkezetét, idézem a Phaidón úgynevezett utolsó érvének azt a részletét, melyben Szókratész a lélek halhatatlanságából annak elpusztíthatatlanságára következtet.

- És ugyanígy a halhatatlan esetében is, ha elfogadjuk, hogy a halhatatlan egyúttal elpusztíthatatlan, akkor a lélek azon túl, hogy halhatatlan, nyilván egyben elpusztíthatatlan is. Ha viszont ezt nem fogadjuk el, akkor másik érv után kell néznünk.

- Nos, ehhez nem kell másik érv. Mert aligha lesz olyasmi, ami ne fogadná be a pusztulást, ha még a halhatatlan, vagyis az örök, sem ilyen és ő is befogadja a pusztulást.

- Márpedig azzal mindenki egyetértene, hogy az isten, aztán az élet formája, és ami halhatatlan még csak van, az nem pusztulhat el.

- Zeuszra, mindenki, az összes ember és az istenek talán még náluk is jobban egyetértenének ezzel. - Ha tehát a halhatatlan egyúttal megsemmisíthetetlen, akkor a lélek, ha egyszer halhatatlan, egyúttal elpusztíthatatlan is, ugye?

- Szükségképpen így van. ${ }^{2}$

Rekapituláljuk az érvet. Szókratész a formaelmélet segítségével bebizonyítja, hogy a lélek halhatatlan (a bizonyításnak ezt a részét később elemzem). Ezután pedig felteszi a kérdést: vajon abból, hogy a lélek halhatatlan (azaz nem fogadhatja be a halált), következik-e, hogy teljességgel elpusztíthatatlan is. Hiszen abból, hogy egy létező nem képes befogadni egy tulajdonság ellentétét (például a tűz nem képes hideggé válni), még nem következik, hogy e tulajdonság megjelenésekor az a létező nem szűnhet meg létezni, azaz nem pusztulhat el. A tüz a hideg megjelenésekor el is pusztulhat és vissza is húzódhat, hiszen mindkét esetben igaz lesz, hogy a tűz nem válhat hideggé. Csak akkor mondhatnánk, hogy a tűz megmarad (azaz visszahúzódik) a hideg közeledtekor, ha az a tulajdonság (a melegség), amivel (modern megfogalmazásban) esszenciálisan rendelkezik, nemcsak a hidegség befogadására, hanem a megsemmisülésre is alkalmatlanná tenné. Mármost a lelket esszenciális tulajdonsága, az élet, nemcsak a halál befogadására teszi alkalmatlanná, azaz nemcsak halhatatlanná teszi, hanem általában képtelenné teszi arra, hogy megszűnjön létezni, azaz hogy elpusztuljon. Az élet (zóé) tehát kiemelt tulajdonság, mely nemcsak ellentéte (a halál) befogadására teszi alkalmatlanná elsődleges hordozóját, a lelket, hanem általában elpusztíthatatlanná is teszi azt.

Nyilvánvaló, hogy Szókratész ezzel a magyarázattal alapozza meg az utolsó érv érvényességét, hiszen mit sem érne azzal, ha a lélek halhatatlan volna ugyan, de elpusztulhatna. Az ilyen értelemben vett halhatatlanságot (vagyis azt a halhatatlanságot,

2 106c-d (Platón 2020, 113). 
melyből nem következik az elpusztíthatatlanság) ugyanis nem szükséges belátni a lélekről. Természetes, hogy - amennyiben a lélek testtől különböző entitás, és Szókratész számára az - akkor nem ugyanazon a módon semmisül meg, mint a test, $s$ ha a test megsemmisülését nevezzük halálnak, akkor a lélek halhatatlan. Ez a halhatatlanság viszont nem ad semmifajta prioritást a léleknek a testtel szemben, hiszen nem jelent többet annál, hogy a lélek nem úgy hal meg, hogy testi komponensekre esik szét, és nem dönti meg Kebész érvét, aki ebben az értelemben elfogadja a lélek halhatatlanságát. ${ }^{3}$ Szókratész tehát azzal cáfolja meg Kebészt és azzal igazolja egyben a lélek testtel szembeni prioritását, hogy megmutatja: az elfogadott premisszák szerint a lélek halhatatlanságából következik annak elpusztíthatatlansága. ${ }^{4} \mathrm{Az}$ érvelést azonban ezen a ponton már az ókorban komoly kritika érte azon az alapon, hogy a következtetés nem helytálló, s így nem bizonyít semmit, csak a lélek előbbi (szigorú) értelemben vett halhatatlanságát.

Lampszakoszi Sztratón - aki több érvet is felhozott a Phaidón halhatatlanságérvei ellen - fogalmazta meg elsőként azt az ellenvetést, mely az utolsó érvben rejlő inkonzisztenciára igyekszik rámutatni. A következőképpen fogalmaz:

[h] Egyáltalán nem magától értetődő, hogy ha [a lélek] nem fogadhatja be a halált és ezért halhatatlan, akkor elpusztíthatatlan is, mert így a kő is halhatatlan, viszont nem elpusztíthatatlan [...] [m] Talán, ahogy a tủz, amíg létezik, addig nem válhat hideggé, ugyanígy a lélek is, amíg létezik, halhatatlan: mert amíg létezik, élettel jár együtt. ${ }^{5}$

3 Azt Kebész is elfogadta, hogy a lélek időtálóbb a testnél, és a test halála nem pusztítja el, csak azt kérdőjelezte meg, hogy a lélek általában elpusztíthatatlan is lenne (lásd Phaidón 88a-b).

4 Egyes feltételezések szerint a fent idézett 106c-d-ben Szókratész és Kebész érvelnek amellett, hogy a halhatatlan miért tekinthető elpusztíthatatlannak. Ennek a lehetséges érvnek részletes leírását és több rekonstrukciós kísérletét adja Gallop 1975, 216-222. Gallop szerint ha van is itt valamiféle érv, akkor sem tekinthető túl meggyőzőnek. A magam részéről inkább Sztratónnal értek egyet, aki láthatóan nem tételez fel érvet. Részint az ad erre a feltételezésre okot, hogy felesleges lenne egy gyenge és egyáltalán nem meggyőző érvet tulajdonítani Szókratésznek, ha van más mód is a konklúzió mellett érvelni, másrészt a szöveg tagadni látszik azt, hogy itt bármiféle érv elhangozna, hiszen Kebész így kezdi válaszát Szókratésznek: „Nos, ehhez nem kell másik érv.” Ez a kezdés pedig explicit módon tagadja, hogy az, ami a következőkben elhangzik, egy újabb érv lenne. Sokkal valószínủbb, hogy Szókratész és Kebész a korábban felvázolt érvelés következményeit diszkutálják.

5 Sztratón, a peripatetikus iskola harmadik vezetője, több ellenvetést hozott fel a Phaidón három érve ellen. Ellenvetései az újplatonikus Damaszkiosz kommentárjában hagyományozódtak, amit Wehrli 1950, 36-37 is közöl, itt a 123-as jeleztü töredék (h) és (m) ellenvetéseit fordítottam le. Az (m) ellenvetést Sedley 2009, 150-153 is elemzi, az ellenvetéseket Hackforth 1955, 195-198 angol fordításban és rövid bevezetéssel ellátva közli. Úgy vélem, a (h) és az (m) ellenvetés szorosan összetartozik, s ugyanarra a problémára mutatnak rá, más irányból (lásd a fordítást követő gondolatmenetet), ezért közlöm mindkét ellenvetést, s nem csak az (m)-et, mint Sedley. 
Az ellenvetés arra támaszkodik, hogy a szigorú értelemben vett halhatatlanságból önmagában véve nem következik az elpusztíthatatlanság, és Szókratész semmilyen további érvet nem mutat be, amelyből ez következne. Az életnek ugyanis a halál az ellentéte, elsődleges hordozója a lélek tehát nem halhat meg, tehát halhatatlan, amint az az utolsó érv premisszáiból következik. A halál azonban nem egyedüli módja az elpusztulásnak, például a kő vagy a tűz sem halhat meg, semmi akadálya viszont, hogy megszűnjenek létezni, vagyis hogy elpusztuljanak. Másfelől az utolsó érv premisszái nem teszik lehetetlenné az elsődleges hordozók megsemmisülését. A tűz nem válhat hideggé, amíg tűzként létezik, lehetséges viszont, hogy ne legyen örökké tűz, azaz hogy elpusztuljon. A lélek helyzete is lehet ezzel rokon: halhatatlan addig, amíg lélekként létezik, ám semmi sem zárja ki, hogy ne legyen örökké lélek. Az ellenvetés alapján tehát a lélek halhatatlansága szigorú értelemben vett halhatatlanság, s Szókratész hibát követ el, amikor ezt az általában vett elpusztíthatatlansággal, vagyis az örökkévalósággal azonosítja.

Azok, akik Sztratón érvét relevánsnak tekintik a kortárs szakirodalomban, ${ }^{6}$ általában kétféleképpen közelítenek az érvhez. Egyesek elfogadva azt, szembenéznek a kérdéssel, hogy Szókratész miért nem gondolta át alaposabban az érvet, és miért nem jött rá, hogy az érv hibás. A. E. Taylor Szókratésznek az érvet lezáró szavaiban véli látni az utalást a hibára: „még a kiinduló feltevéseinket is alaposabban meg kellene vizsgálnunk, bármennyire is hitelt érdemlőnek tartjátok ezeket" ${ }^{7}$ Ez a megoldás azonban problematikus, mert Szókratész sokkal valószínűbben utalhat az érv egészének lehetőséget adó formaelmélet alaposabb megvizsgálására. ${ }^{8}$ David Bostock azt állítja, hogy a dialógus negatív eredménnyel zárul, mert Szókratész olyan logikai hibát vét, melyet sem ő, sem beszélgetőtársai nem vesznek észre (s így maga a szerző, Platón sem). Ez a feltevés kérdésessé válik annak fényében, hogy a beszélgetés kimenetelének valós tétje van (nevezetesen, hogy Szókratész mint igazi filozófus helyesen dönt-e, amikor nem menekül a halál elől és többre tartja azt az életnél). Azt, hogy Bostock érvelése ezen a ponton véleményem szerint elhibázott, az egész következő gondolatmenet hivatott megmutatni, itt csak jelzek egy olyan problémát, ami kérdésessé teszi az általa felhozottakat. ${ }^{9}$ Más értelmezők úgy vélik, hogy Sztratón érve nem helytálló. Dorothea Frede a Phaidón utolsó érvéről szóló egyik tanulmányában a lélek halhatatlansága mellett felhozott első, úgynevezett ciklikus érv segítségével kíván rámutatni Sztratón gondolatmenetének hibájára (mindamellett, hogy az utolsó érv egészét természetesen ő sem fogadja el). ${ }^{10}$ David Sedley egy korábban már hivatkozott cikkében a következő érvet hozza Sztratón ellen. A lélek halhatatlan, mert esszenciális tulajdonsága az, hogy él, és így - a Phaidón pre-

6 Általános leírást és szakirodalmi tájékoztatót nyújt a végső érvhez Meinwald 2016, 134-143.

7 Phaidón 107b3-4.

8 Taylor 1997, 291-292.

9 Bostock 1986, 189-193.

10 Frede 1978, 30-32. 
misszái alapján - képtelenség feltételezni róla, hogy halott. Ezen a képtelenségen nem változtat az, hogy létezik-e vagy sem, hiszen egy nemlétező dologról is tehetek olyan állításokat, melyek logikailag ellentmondásosak. Azt, hogy a lélek elpusztíthatatlan is, abból a további premisszából vezeti le Sedley, hogy az élőlények esetében az, ami elpusztult, halott. ${ }^{11}$

A következőkben amellett érvelek, hogy a Phaidón korábbi részeiben (az utolsó érv elején és az úgynevezett affinitás érvben) elfogadott premisszák szerint Sztratón érve nem helytálló. Nem állítom azt, hogy Szókratész valóban bebizonyítja a lélek halhatatlanságát, hiszen nem vagyunk kötelesek elfogadni az általa használt meghatározásokat és premisszákat, a dialógus meghatározásai mellett viszont indokoltnak látom az utolsó érv következtetéseit.

\section{A halál két meghatározása}

Az előbbi, szigorú értelemben vett halhatatlansághoz nyilvánvalóan társul egy megfelelő haláldefiníció, illetve a tágabb értelemben vett halhatatlansághoz, vagyis az elpusztíthatatlansághoz is társul egy hasonló meghatározás. Ha sikerül megmutatni, hogy az utolsó érvben Szókratész tágabb értelemben veszi a halált és halhatatlanságot, akkor Sztratón érve is megcáfolható lesz. Kezdjük a halál szigorúbb és tágabb meghatározásának, valamint a köztük levő különbségnek a bemutatásával.

Már a Phaidón elején - Szókratész úgynevezett „védőbeszédének” kezdetén - meghatározásra kerül a halál mint a lélek elválása a testtől. ${ }^{12}$ Ezt a meghatározást nevezem szigorúnak. A testből és lélekből álló emberi lény számára a halál, avagy a megsemmisülés valóban az, hogy két lényegi alkotórésze, a test és a lélek, megszűnik összekapcsolódni. Az emberi lény ekkor megsemmisül, de teste és lelke ettől még megmarad, csakhogy nem a korábbi - összekapcsolt - módon fognak létezni, hanem külön-külön. Azért tekinthető tehát e meghatározás szigorúnak, mert az így felfogott halál csak az ember mint egész megszüntét jelenti, s ebben az értelemben még a test is lehetne halhatatlan. Az viszont megfigyelhető, hogy az emberi test nem halhatatlan, s halandósága épp abban áll, hogy miután az életadó lélek elhagyja, alkotórészeire esik szét. A test halandósága tehát egy tágabb értelmét tételezi fel a halálnak, s nyilvánvaló, hogy a lélek halhatatlanságának vizsgálata során szintén ezt a tágabb értelmet használja fel Szókratész. Mi tehát ez a tágabb értelemben vett halál, és hol kerül először meghatározásra? A tágabb

11 Sedley 2009, 150-153.

12 64c-d: „Azt gondoljuk, hogy van olyan valami, ami a halál, ugye? [...] És ez nem más, mint a léleknek a testtől való elválása." 
értelemben vett halál nem lehet más, mint az alkotórészekre való szétesés. Ebben az értelemben pedig a halál azonos az elpusztulással, hiszen mi más volna egy entitás elpusztulása, mint az, hogy alkotórészeire esik szét, azaz megszűnik azon a módon létezni, ahogy eddig, és mint önmaga létezett. A test is miután a lélek elhagyja, bizonyos idő elteltével alkotórészeire esik szét, azaz elpusztul, megszűnik testként létezni. Szókratész tehát a lélek halhatatlanságát ebben, és nem a korábbi értelemben veszi. ${ }^{13}$

Érdemes idézni a dialógusból az úgynevezett affinitás érv elejét, ahol Szókratész a tágabb értelemben vett halált határozza meg:

Még mindig ott van az a szokásos ellenvetés, amit Kebész az előbb említett: hogy esetleg az ember halálával a lélek is feloszlik és létezése ezzel véget is ér. Mert mi szól az ellen, hogy valamikor maga a lélek is létrejött, tehát valahonnan és valahogyan összeállt, és az emberi testbe költözés előtt is létezett már, de végül ő is meghal és elpusztul, amikor majd elhagyja azt a testet, amelybe beköltözött? [...] Valami mégis azt súgja nekem, hogy te és Szimmiász ezt a kérdést is szeretnétek tüzetesebben megvizsgálni, mert mint a gyerekek még mindig attól féltek, hogy a szél esetleg tényleg elfújja és szétszórja a lelket, ahogy a testből kilép - főleg ha valakit véletlenül nem szélcsendben, hanem jó nagy szélben érne a halál. ${ }^{14}$

Az idézetből egyrészt kitűnik az, hogy a beszélgetés igazi célja a lélek tág értelemben vett halhatatlanságának bizonyítása. Másrészt, hogy a halál a lélek esetében valóban azonosítva van a részekre eséssel, vagyis a pusztulással. A végső érvben nem változtat Szókratész ezeken a kitételeken, csak hozzájuk veszi a formaelmélet premisszáit. Jogos tehát azt gondolni, hogy a végső érv kulcsa (a formaelmélet mellett) az, hogy a lélek halhatatlansága tágabb értelemben vett halhatatlanság.

\section{A tágabb értelemben vett halhatatlanság és Sztratón érve}

Ha Szókratész az utolsó érvben a lélek tágabb értelemben vett halhatatlanságát bizonyítja be, akkor (az előző részben mondottak alapján) valóban nem kell másik érvet

13 Mint a következőkben utalok is rá, a tágabb értelemben vett halhatatlanság az elpusztíthatatlanságot jelenti. Azért használom ezt a talán kissé zavarba ejtő megfogalmazásmódot, hogy érzékeltessem: a szükebb értelemben vett halál, azaz a lélek elválása a testtől, valójában csak egy fajtája a pusztulásnak, az a fajta pusztulás, ahogyan egy élőlény, pl. Szókratész, elpusztul. Az élőlény halála ugyanis nem jelent többet, mint azt, hogy alkotórészeire - testre és lélekre - esik szét, ilyen formán pedig a halál csak a pusztulás (részekre való szétesés) egyik fajtája.

14 Phaidón $77 \mathrm{~d}-\mathrm{e}$. 
keresni az elpusztíthatatlanság belátásához, hiszen a tágabb értelemben vett halhatatlanság azonos az elpusztíthatatlansággal. Sztratón érve tehát hibás. Érdemes azonban felvetni, hogy miért jár együtt az élet - mely a lélek esszenciális tulajdonsága - a tágabb értelemben vett halhatatlansággal. Az élet az emberi lény egészét jellemzi, és így már a szűkebb értelemben vett halál is az élet megszüntét jelenti, de csak az ember (vagy más élőlény) mint egész számára. Az élőlények pedig nem esszenciálisan rendelkeznek az élettel, csak azért élnek, mert lelkük van. A lélek életének pedig nyilván nem vethet véget a szűkebb értelemben vett halál, hiszen a lélek nem tevődik össze testből és (egy további) lélekből, hanem mint egész hordozza esszenciálisan az életet. A lélek halála tehát csak tágabb értelemben vett halál lehet. Ez a tágabb értelemben vett halál lesz tehát az élettel ellentétes. A pusztulás (vagyis a tágabb értelemben vett halál) a melegséget vagy a páratlanságot is megszünteti, s ettől még nem ellentétes ezek egyikével sem. A lélek esetében azonban más a helyzet. A lélek ugyanis esszenciálisan él, $s$ az élettel ellentétes a halál. A lélek halála viszont csak tágabb értelemben vett halál, vagyis pusztulás lehet, hiszen a szűkebb értelemben vett halál nem alkalmazható rá, és nemcsak azért nem alkalmazható, mert a lélek él, hanem a lélek életétől független okok miatt sem.

A következő analógiával világítom meg, mire gondolok. Tegyük fel, hogy a halálhoz hasonlóan a hidegség is két értelemben vehető. A szükebb értelemben vett hidegség legyen a megfagyás, a tágabb értelemben vett hidegség pedig a hőmérsékletcsökkenés. A Phaidón premisszái szerint a tűz, mint a melegség elsődleges hordozója, nem fogadhatja be a hidegséget. Ha feltesszük, hogy a hidegség kétféle értelemben vehető, akkor joggal merül fel a kérdés, hogy melyik értelemben vett hidegséget nem fogadhatja be a tüz. Nyilván akkor lehet csak azt állítani, hogy a tüz nem válhat hideggé, ha a tágabb értelemben vett hidegséget nem fogadhatja be. Hiszen lehet valami úgy hideg, hogy a hidegség szűkebb értelme szerint nem hideg, azaz nem fagyott. Másfelől a tűz nem fagyhat meg, tehát a szükebb értelemben vett hidegség nem alkalmazható rá. Az is világos viszont, hogy nemcsak azért nem lehet fagyott a tüz, mert elsődleges hordozója a melegségnek, hanem más, melegségétől független okok miatt sem - például azért sem, mert nincs benne folyadék, ami megfagyjon. A hidegség szűkebb érteleme tehát nemcsak azért nem alkalmazható a tủzre, mert a tủz esszenciálisan meleg, hanem azért sem, mert a tűz olyan jellegű entitás, melynek természete nem engedi meg, hogy megfagyjon. A fenti premisszából viszont az következik, hogy a tűz nem képes befogadni a hidegséget. Az a hidegség, amit nem képes befogadni, nem lehet pusztán a szükebb értelemben vett hidegség, mert azt nem melegsége miatt, hanem más - melegségétől független - okok miatt nem képes befogadni. Lesz viszont valamilyen sajátos hidegség, melyet - noha elvileg alkalmazható lenne rá - csak azért nem képes befogadni, mert az a benne lévő melegséggel ellentétes. Ugyanezt másként is meg lehet fogalmazni. A tűz nem fagyhat meg részben azért, mert esszenciálisan meleg, részben más miatt. Ami az első okot illeti, 
az általában azt zárja ki, hogy a tűz hideg legyen, azaz nem speciálisan a megfagyásra vagy szűkebb értelemben vett hidegségre vonatkozik, hanem a szűkebb értelemben vett hidegség hidegség voltára, mely mindenféle hidegségben azonos, azaz megegyezik a tágabb értelemben vett hidegséggel. Mindezt a lélekre alkalmazva: a szűkebb értelemben vett halál nemcsak azért nem alkalmazható a lélekre, mert a lélek esszenciálisan él, hanem egyéb - a lélek élő voltától független - okok miatt sem. Lesz viszont egyfajta halál, mely elvileg alkalmazható lenne ugyan a lélekre, s csupán amiatt nem alkalmazható, mert a lélek esszenciálisan él. Ez a halál pedig csak a tágabb értelemben vett halál lehet, mivel a szűkebb értelemben vett halál elvileg sem alkalmazható a lélekre, azaz a lélek élő voltától független okok miatt sem. Másként megfogalmazva: a szűkebb értelemben vett halálban az, ami azért nem alkalmazható a lélekre, mert a lélek él, egybeesik a tágabb értelemben vett halállal. A lélek tehát nem fogadhatja be a tágabb értelemben vett halált, azaz a lélek elpusztíthatatlan.

Az utolsó érvből kiderül, hogy az élethez tartozik saját forma. ${ }^{15} \mathrm{Az}$ azonban nem egyértelmü, hogy a halálhoz is tartozik-e ilyen. ${ }^{16}$ Amennyiben nem tartozik, akkor nem alkalmazható ugyanazon modell a lélekre, ami a tűzre, a háromra és más elsődleges hordozókra alkalmazható volt. A modell szerint ugyanis egy adott forma elsődleges hordozója nem képes befogadni az azzal a formával ellentétes formát. A tüz, mely eszszenciálisan meleg, nem válhat hideggé úgy, ahogyan a melegség formája sem részesedhet a hidegség formájából soha. Hasonló módon a három, mely esszenciálisan páratlan, nem fogadhatja be a párosságot úgy, ahogyan a páratlanság formája sem részesedhet a párosság formájából soha. A lélek, mely esszenciálisan él, nem fogadhatja be a pusztulást úgy, ahogyan az élet formája sem részesedhet a pusztulásból. Ahhoz azonban, hogy ez az elgondolás alkalmazható legyen, szükséges, hogy a pusztulásnak is legyen saját formája. Másként ugyanis a dolgok pusztulása derivatív, azaz más (saját formával rendelkező) okokból származik. Ez esetben viszont nem lehet pusztulásról, mint olyanról beszélni, csak ennek vagy annak a dolognak a pusztulásáról, ez pedig alkalmazhatatlanná teszi a fenti modellt, hiszen az élet formájának nem lesz sajátos ellentéte. Ez a meg-

15 A fent idézett 106c-d részlet teszi ezt egyértelművé: „Márpedig azzal mindenki egyetértene, hogy az isten, aztán az élet formája, és ami halhatatlan még csak van, az nem pusztulhat el.” Nem térek ki itt ennek a sornak egy másik fontos részére, arra, hogy mi a kapcsolat az isten és a formák között, ez a kérdés ugyanis témám szempontjából irreleváns. Azt sem vizsgálom, hogy az élet formája milyen típusú formának tekinthető, mivel a szöveg egyértelművé teszi, hogy van az életnek formája, s ez már elegendő a lélek halhatatlansága szempontjából. Ettől függetlenül fontos a kérdés, hogy az élet formája milyen kapcsolatban áll a többi formával, s hogy vajon, ahogy elsődleges hordozója, a lélek - mint látni fogjuk - kitüntetett a többi elsődleges hordozók között, nem kitüntetett-e ugyanilyen módon az élet formája is a többi formák között.

16 A következőkben amellett érvelek, hogy a halál formáját, legalább ennek az érvnek az erejéig, fel kell tételezni, természetesen ez nem jelenti azt, hogy Platón mindig elfogadná a pusztulás formáját. Az Állam 608c-611a2 halhatatlanság érve egyértelmủen tagadni látszik a pusztulás formáját. A halál itt a tág értelemben vett halál, vagyis a pusztulás. 
közelítés viszont nem felelhet meg az utolsó érv premisszáinak, Szókratész ugyanis épp abból indult ki, hogy az olyan okok, melyek nem alkalmazhatók általános érvénnyel minden dologra, nem tekinthetők oknak. ${ }^{17}$ Egy szép tárgy szépsége nem vezethető vissza színére vagy alakjára, más szép tárgyak ugyanis más okokból szépek. S éppen ezért van szükség a formaelméletre, mely kielégítő módon megmagyarázza, hogy a dolgok miért szépek, miért nagyok stb. Ha viszont elfogadjuk, hogy nincs a pusztulásnak mint olyannak sajátos formája, akkor az okozásnak ahhoz a fajtájához jutunk vissza, melynek tagadásából kiindultunk. Ilyen felfogás mellett az egyik dolog azért pusztul el, mert felmelegszik, a másik azért, mert lehűl, de nem tudjuk megadni a pusztulás általános okát. Ilyen ok - az utolsó érv premisszái szerint - csak akkor adható, ha feltételezzük, hogy a pusztulásnak saját formája van.

A pusztulásnak tehát rendelkeznie kell formával, s ez a forma ellentéte az élet formájának. A lélek pedig, mely elsődleges hordozója az életnek, nem fogadhatja be a pusztulást. A lélek tehát elpusztíthatatlan. Így Sztratón érve erejét veszti. Hátra van még annak vizsgálata, hogy az utolsó érvben belátott elpusztíthatatlansággal hogyan kerül a lélek metafizikailag kiemelt pozícióba. Mit igazolt Szókratész a lélek elpusztíthatatlanságával?

\section{A lélek elpusztíthatatlanságának „haszna”}

Azzal, hogy Szókratész belátja a lélek elpusztíthatatlanságát, kiemeltté teszi a lelket. De mit jelent, miben áll ez a kiemeltség? A lélek elsődleges hordozója az életnek, hozzá hasonlóan más elsődleges hordozók is vannak. A tűz elsődleges hordozója a melegségnek, a hó a hidegségnek, a három a páratlanságnak stb. ${ }^{18}$ Ezek az elsődleges hordozók kulcsszerepet töltenek be a Phaidón metafizikájában. A többi érzékelhető dolog ugyanis ezeken keresztül részesedik a formákból. Egy emberi test azáltal válik meleggé, hogy részesedik a tűzből. Közvetve természetesen a melegségtől válik meleggé, hiszen a tűz is azért meleg, mert a melegségből részesedik. Közvetlenül viszont csak az elsődleges hordozók részesednek a formákból, a többi dolog közvetve - a hordozókkal rendelkezve részesedik belőlük, emiatt hívhatjuk az elsődleges hordozókat elsődlegesnek, hiszen közvetlenül csak ezek részesülnek a formákból.

Foglaljuk össze, mire jutottunk. Vannak olyan entitások,

(1) melyek maguk nem formák, de közvetlenül részesednek egy formából;

17 Phaidón 96e4-97b4, ennek a résznek az elemzéséhez lásd Vlastos 1971, 137-158.

18 A példákhoz lásd Phaidón 103d-104c. 
(2) melyek esszenciális tulajdonsága az a tulajdonság, aminek a formájából részesednek;

(3) melyekkel rendelkezve az érzékelhető dolgok részesednek a megfelelő formákból, vagyis rendelkeznek a megfelelö tulajdonsággal.

Ezeket az entitásokat nevezem elsődleges hordozóknak. ${ }^{19} \mathrm{Az}$ is világos, hogy a lélek egy elsődleges hordozó, az élet formájának elsődleges hordozója. A léleknek van azonban egy negyedik, a fent felsoroltaktól eltérő tulajdonsága, az elpusztíthatatlanság. Nem minden elsődleges hordozóra igaz az, hogy elpusztíthatatlan, jóllehet az mindegyikre igaz, hogy a formájukkal ellentétes formát nem képesek befogadni, hiszen a formájuknak megfelelő tulajdonsággal esszenciálisan rendelkeznek. ${ }^{20}$ A legtöbb formával nem ellentétes a pusztulás. Az élet formája azonban - a fentiek alapján - ellentétes a pusztulással, $s$ a lelket elpusztíthatatlanná teszi. Az elpusztíthatatlanság pedig a formáknak is tulajdonsága, amint az affinitás érvből kitűnik. Ami elpusztíthatatlan az egyszerủ (nem összetett) és intelligibilis, tehát formajellegü. Az elpusztíthatatlanság és a formajelleg mindig együtt jár. Ha tehát a lélek elpusztíthatatlan, akkor formajellegü, a formajelleg pedig kiemeli a lelket a többi elsődleges hordozók közül. A nem formajellegü elsődleges hordozók maguk is az érzékelhető dolgok körébe tartoznak, a lélek viszont formajellegü entitás. Természetesen nem forma ${ }^{21}$ hiszen elsődleges hordozó és így van benne hasonlóság az érzékelhető dolgokkal is, de elpusztíthatatlansága a formákhoz teszi hasonlóvá. A lélek tehát köztes létező.

Az eddigiek a következőképpen foglalhatók össze. A formák mind létezés, mind okozás szempontjából elsődleges létezők, az elsődleges hordozók esszenciálisan hordozzák a formáknak megfelelő tulajdonságot, az érzékelhető dolgok pedig az elsődleges hordozókból részesedve részesednek a formákból, s létezésük is ennek köszönhető. ${ }^{22} \mathrm{Az}$ elsődleges hordozók általában érzékelhető dolgok, egyedül a lélek az, ami rendelkezik formajelleggel is, és így nem érzékelhető dolog. Éppen ezért a lélek nem egyszerűen el-

19 Az elsődleges hordozó kifejezés a sajátom. Sedley 2009, 152 az essential bearer (esszenciális hordozó) terminust használja, ám azért részesítem előnyben az elsődleges hordozó nevet, mert így elkerülöm azt az arisztoteliánus értelmezést, melyet az esszenciális jelző sugall. Máté 2020, 158 a Leibniztől származó karakter elnevezést használja, ez a terminus viszont egy, a fentiekben meghatározottnál tágabb kategória lefedésére szolgál.

20 Phaidón $104 \mathrm{~b}-\mathrm{c}$.

21 Nyilvánvaló, hogy az egyes, egyedi lelkek nem lehetnek formák. Következik ez például abból, hogy minden formából csak egy van, az egyedi lelkekből viszont több, nem felelhetnek meg hát valamelyik formának. Abban a kérdésben, hogy a léleknek van-e általános, saját formája, nem foglalok állást. Újabban Prince 2011,1-34 érvelt amellett, hogy a lélek formájának feltételezése megkönnyíti az utolsó érv értelmezését.

22 Phaidón 105b-d. Nem kerül tárgyalásra a Phaidónban, hogy az elsődleges hordozók és a formák között milyen kapcsolat áll fenn, azzal kapcsolatban, hogy itt valószínűleg nem egyszerủen részesedésről van szó lásd Máté 2020, 158-159. 
sődleges hordozó, hanem köztes létező is, olyan létező, mely képes mind az érzékelhető dolgokkal, mind a formákkal kapcsolatba lépni. A lélek a formákkal az értelmi megismerés útján lép kapcsolatba, az érzékelhető dolgokkal pedig mint az élet elsődleges hordozója. Itt kapcsolódik tehát össze a lélek két különböző funkciója: az értelem ahhoz szükséges, hogy a lélek saját formajellegét felismerve kapcsolatba lépjen a formákkal, életprincípiumként pedig az érzékelhető dolgokkal kerül kapcsolatba.

Innen nézve válik megmagyarázhatóvá a lélek „eltestiesülése” ${ }^{23}$ is. Amennyiben nem használja értelmét a lélek, akkor távol kerül formajellegétől, s puszta elsődleges hordozóként működik. Minthogy nem ismeri meg saját természetét, a halál után nem kerülhet a formák közelébe, hanem más élőlényekbe költözve mint életprincípium funkcionál. Ha ellenben ráébred saját formajellegére, akkor a halál után is folytathatja a formák megismerését, s elsődleges hordozói jellege háttérbe szorul. A formák ugyanis elsődlegesek a létezés szempontjából, s így a formajelleg is elsődleges más jellegekkel szemben.

Mindezek a megállapítások a lélekről már az affinitás érvben ${ }^{24}$ is elhangzottak, csakhogy fordított irányból. Ott a lélek formajellegét feltételezve jutott Szókratész oda, hogy a léleknek halhatatlannak kell lennie, azaz nem bebizonyította, hanem feltételezte a lélek formaszerűségét. A végső érv épp arra szolgál, hogy pusztán a formaelmélet premisszáiból kiindulva bizonyítást nyerjen a lélek halhatatlansága, s így általában formajellege. A két érv tehát szorosan összekapcsolódik, a halhatatlanság azonosítása az elpusztíthatatlansággal azért is fontos, mert így a lélek belső természetének elsődlegessége is bizonyítást nyer.

\section{Bibliográfia}

Apolloni, David. 1996. „Plato's Affinity Argument for the Immortality of the Soul.” Journal of the History of Philosophy 34/1: 5-32.

Bostock, David. 1986. Plato’s Phaedo. Oxford: Clarendon Press.

Frede, Dorothea. 1978. „The Final Proof of the Immortality of the Soul in Plato's Phaedo 102a-107a." Phronesis 23/1: 27-41.

23 Phaidón 81c-d. A lélek erkölcsi romlásának fö okát a testre hivatkozva magyarázza a Phaidónban Szókratész. A végső érv gondolatmenetével összekapcsolva az affinitás érvet a következő mondható erről röviden: a lélekben megvan az elsődleges hordozói jelleg, mely összekapcsolja a testtel, és az elpusztíthatatlanságból eredő intelligibilis jelleg, mely összekapcsolja a formákkal. Minthogy képes a testtel összeköttetésbe lépni, összeköttetésbe léphet a lélek a romlandóval. Amennyiben ezt tartja szem előtt, olyan dolgokat igyekszik majd megismerni, melyek valójában nem megismerhetőek. Hiszen a romlandóra nem vonatkozhat valódi tudás, éppen romlandóságából eredően. Az a lélek tehát, mely elsődleges hordozói jellegét helyezi előtérbe, nem rendelkezhet valódi tudással, s Szókratész etikai intellektualizmusából következik, hogy bünös is lesz.

24 Az affinitás érv általános elemzéséhez lásd Apolloni 1996, 5-32. 
Gallop, David. 1975. Plato. Phaedo. Oxford: Clarendon Press.

Hackforth, Reginald. 1955. Plato's Phaedo. Translated with an Introduction and Commentary. Cambridge: Cambridge University Press.

Máté András. 2020. Utószó. Phaidón, Platón, 131-166. Budapest: Atlantisz.

Meinwald, Constance. 2016. Plato. London - New York: Routledge.

Platón. 2020. Phaidón, szerk. és ford. Bárány István - Máté András. Budapest: Atlantisz.

Prince, Brian D. 2011. „The Form of Soul in the Phaedo." PLATO. The electronic Journal of the International Plato Society 11: 1-34.

Sedley, David. 2009. „Three kinds of Platonic immortality”. In Body and Soul in Ancient Philosophy, szerk. Dorothea Frede - Burkhard Reis, 145-162. Berlin - New York: Walter de Gruyter.

Taylor, Alfred E. 1997. Platón. Ford. Bárány István - Betegh Gábor. Budapest: Osiris Kiadó.

Vlastos, Gregory. 1971. „Reasons and Causes in the Phaedo.” In Plato. A Collection of Critical Essays. I: Metaphysics and Epistemology, 132-167. London: Palgrave Macmillan.

Wehrli, Fritz. 1950. Die Schule des Aristoteles. Texte und Kommentar. Straton von Lampsakos. Basel: Benno Schwabe \& Co. Verlag. 